\title{
Screening of Sri Lankan Rice (Oryza sativa L.) Landraces for Drought Tolerance
}

\author{
S.P. Munasinghe, S. Somaratne ${ }^{1}$ and S.R. Weerakoon ${ }^{1 *}$ \\ Department of Botany \\ The Open University of Sri Lanka \\ Nawala, Sri Lanka.
}

\begin{abstract}
Twenty four (24) traditional Sri Lankan rice landraces were screened for drought tolerance at seedling stage in the greenhouse at the Open University of Sri Lanka, Nawala. Four week old seedlings grown in pots filled with soil were exposed to drought condition by disconnecting water supply for two weeks. Drought tolerance was evaluated by measuring plant height and leaf width after two weeks of recovery. Agro-morphological characterization of rice landraces was made on vegetative characters and yield attributed characters. The Simple Sequence Repeat (SSR) marker analysis was employed to determine the association between allelic diversity and drought tolerance of traditional rice landraces. Comparatively, the landraces Suwandal, Kirimurunga and Suduru samba showed tolerance to drought. Meanwhile, the SSR marker RM252 have shown the potential candidacy for tracing drought tolerance compared to other markers used in the study.
\end{abstract}

Keywords: Drought tolerance, SSR markers, Traditional rice landraces

\section{INTRODUCTION}

Rice is the staple food in Sri Lanka and the total extent of cultivated rice is 34\% of the arable land.Rice is cultivated during two seasons Yala (dry) and Maha (wet). Yala season experience longer dry conditions while Mahahas comparatively shorter periods of drought. The extent of land cultivated under the Yala season is less than that of Maha. Further, climate condition of Sri Lanka is experiencing unexpected fluctuations of extended dry spells all over the island. Most of cultivated area (70\%) lies in North, North Central, Eastern and Uva Provinces which are highly vulnerable to the climate change (Somaratne and Dhanapala, 1996).These unexpected changes and the present trends of changing climate over the island threaten national food security.

The drought affects crop yield by interrupting floret initiation and grain filling in reproductive stage of the plant (Mostajeran and Rahimi-Eichi, 2009). The response of rice to drought depends on the developmental stage of canopy and alters water use efficacy by changing the leaf water potential leading to a high demand of transpiration water (Boonjung and Fukai, 1996). In addition, drought reduce nutrient uptake by lowering the absorption of inorganic nutrients (Farooq et al., 2009). Further, decreased availability of $\mathrm{CO}_{2}$ limits the stomatal diffusion of $\mathrm{CO}_{2}$, and as consequence, mesophyll cells lead to an alteration of photosynthesis due to drought stress (Chaves et al., 2009). The drought induce formation of

\footnotetext{
1 Department of Botany, The Open University of Sri Lanka, Nawala, Sri Lanka

* Corresponding author: shyamaweerakoon@gmail.com
} 
the reactive oxygen species (ROS) including superoxide radical, hydroxyl free radical (.OH), hydrogen peroxide $\left(\mathrm{H}_{2} \mathrm{O}_{2}\right)$ and atomic oxygen which cause peroxidation of lipids, denaturation of proteins, mutation of DNA causing various types of cellular oxidative damage bringing burnt leaves in the plant (Sharma and Dubey, 2005).

Studies show that Traditional agriculture practices coupled with native paddy varieties have proven to be more successful in facing climate change events such as droughts (Sharma and Rai, 2010). It has been reported that Sri Lankan rice cultivars consists of many abiotic and biotic stress tolerant traits with diverse agronomical characters (Ranawaka and Dahanayake, 2012). Cultivars showing these traits are of importance in breeding programs to produce drought tolerance rice cultivars in Sri Lanka.

The natural genetic variation of rice germplasm is often explored by subjecting the rice plant to stressed environments or by identificationof quantitative trait loci (QTLs) which can subsequently be used with marker-assisted selection (De Costa et al., 2012). The markers such as SSR, RM are used in breeding for the identification and/or confirmations of traits of importance. These technologies minimize the difficulties in preparation of sample, time consuming processes and derived information are deliberately informative (Matin et al, 2012). Therefore, the objectives of the present study were to screen the drought tolerance traditional rice landraces by means of morphological characters and SSR markers, and selecting appropriate markers for occurrence of drought tolerance trait.

\section{MATERIALS AND METHODS}

Twenty four rice varieties were obtained from Rice Research and Development Institute, Batalagoda, Sri Lanka for the study. Among them, the rice cultivar Dular was indicated as a drought resistant variety (Hoque and Kobata, 1998). Others were traditional rice varieties in Sri Lanka. The experiments were carried out in a green house in The Open University of Sri Lanka, Nawala, Sri lanka.

Seeds were allowed to break dormancy at $50{ }^{\circ} \mathrm{C}$ for 5 days. Seed surface was sterilized by keeping them in $70 \%$ alcohol for 2 minutes. Seeds were washed thoroughly with distilled water and were dipped them in $2 \%$ Clorox for about 30 minutes. Finally they were thoroughly washed with distilled water and kept in an incubator at $35{ }^{\circ} \mathrm{C}$ for seven days under dark conditions. Germinated seeds were planted in plastic buckets filled with soil collected from paddy fields, up to $3 / 4$ of the total depth according to Completely Randomized Design (CRD) with 3 replicates and 5 plants per replicate. From these plants, data of vegetative characters, yield and yield attributed characters were taken. These characters were shoot length $(\mathrm{cm})$, number of tillers/plant, number of reproductive tillers/plant, panicle length $(\mathrm{cm})$, number of spicklets/plant, number of fertile spicklets/plant, grain yield/plant $(\mathrm{g})$ and hundred seed weight $(\mathrm{g}) /$ plant.

Dormancy broken seeds were sterilized and allowed to germinate. Experiment was conducted at seeding stage. Plants were grown in two experiments under stress and non stress conditions. Germinated seeds were planted in plastic buckets filled with homogenized soil up to $3 / 4$ of the total depth in a Completely Randomized Design with 3 replicates and 5 plants/replicate. Supplying of water was discontinued four weeks after planting. Two weeks after $80 \%$ of the plants were allowed to completely wither; plants were evaluated for drought resistance by measuring plant height and leaf-width of the recovered plants. 
Seeds of rice landraces were grown in soil filled plastic trays for two weeks and leaves were harvested. Total genomic DNA was extracted using Quagen plant DNA extraction kit. Randomly selected four (4) drought-tolerances related SSR markers (Table 1) (RM252, $R M 234, R M 242$ and $R M 2125$ ) were used to screen rice varieties using extracted DNA from seedlings. PCR amplification reactions were done in $12.5 \mu \mathrm{l}$ reaction volume.SSR markers were amplified by thermo cycler (Gradient Thermal Cycler-Life ECO TC-96/G/H(b)C. Bir/ferrotec) as follows: 35 cycles of $5 \mathrm{~min}$ initial denaturation at $95{ }^{\circ} \mathrm{C}$, denaturation for 1 min at $95{ }^{\circ} \mathrm{C}$, annealing for $1 \mathrm{~min}$ at $55^{\circ} \mathrm{C}$, extension for $2 \mathrm{~min}$ at $72{ }^{\circ} \mathrm{C}$ and final extension at $72{ }^{\circ} \mathrm{C}$ for $7 \mathrm{~min}$. Amplified products were separated by $1 \%$ Agarose Gel Electrophoresis.

Table 1. Selected SSR markers for drought and salinity tolerance

\begin{tabular}{lllcc}
\hline Locus & Location & \multicolumn{1}{c}{ Sequence } & $\begin{array}{c}\text { Anneling } \\
\text { Temperature } \\
\text { ('C) }\end{array}$ & $\begin{array}{c}\text { Product } \\
\text { size/range } \\
\text { (bp) }\end{array}$ \\
\hline RM252F & Chr.4 & TTCGCTGACGTGATAGGTTG & & \\
RM252R & Chr.4 & ATGACTTGATCCCGAGAACG & 55 & 216 \\
RM234F & Chr.7 & ACAGTATCCAAGGCCCTGG & & 156 \\
RM234R & Chr.7 & CACGTGAGACAAAGACGGAG & 55 & \\
RM242F & Chr.9 & GGCCAACGTGTGTATGTCTC & & 225 \\
RM22RR & Chr.9 & TATATGCCAAGACGGATGGG & 55 & \\
RM 2125F & Chr.10 & TACCTCCTAGCTTTACTTAT & & $72-123$ \\
RM2125R & Chr.10 & ACTGATCTCTATCTCATTGT & 55 & \\
\hline
\end{tabular}

Source: Khowajaet al., (2009), Islam et al., (2012)

The summary of statistics such as mean and standard deviation were calculated for Agromorphological measurements using SPSS PC Ver.23.

\section{RESULTS AND DISCUSSION}

The tested landraces showed significant variation with respective agro morphological characters (Table 2). The shoot length ranged from $78.6 \mathrm{~cm}$ to $168.2 \mathrm{~cm}$ and among the tested cultivars five of them showed shoot length above $120 \mathrm{~cm}$ while $M a$ weewas the tallest $(168.2 \mathrm{~cm})$ and Kaluheenatiwas the shortest $(78.6 \mathrm{~cm})$. Highest number of tillers was observed in the cultivar Halsudu wee which is seven tillers but majority of cultivars $(62.5 \%)$ was less than 5. The highest number of reproductive tillers was seen in cultivar Rathuheenati. The longest panicle, highest number of spicklets and fertile spickets were seen in cultivar Godaheenati. However the highest 100 seed weight was observed in Murungakayan.

Table 2. Summary of the traits of rice landraces.

\begin{tabular}{lccccccc}
\hline Cultivar & $\begin{array}{c}\text { Shoot } \\
\text { length } \\
\text { (cm)L }\end{array}$ & $\begin{array}{c}\text { Number } \\
\text { of tillers }\end{array}$ & $\begin{array}{c}\text { Number of } \\
\text { reproducti } \\
\text { ve tillers }\end{array}$ & $\begin{array}{c}\text { Panicle } \\
\text { length } \\
\text { (cm) }\end{array}$ & $\begin{array}{c}\text { Number } \\
\text { of } \\
\text { spikelets }\end{array}$ & $\begin{array}{c}\text { Number } \\
\text { of fertile } \\
\text { spikelets }\end{array}$ & $\begin{array}{c}\text { Weight } \\
\text { of 100 } \\
\text { (g) }\end{array}$ \\
\hline Kuruluthuda & 129.7 & 5 & & & & \\
& $(10.9)^{\mathrm{a}}$ & $(0.57)^{\mathrm{b}}$ & & & & \\
\hline Ma wee & 168.2 & 4 & & & & \\
& $(1.2)^{\mathrm{a}}$ & $(0.33)^{\mathrm{c}}$ & & & & \\
\hline
\end{tabular}




\begin{tabular}{|c|c|c|c|c|c|c|c|}
\hline Dular & $\begin{array}{l}121.8 \\
(3.1)^{b}\end{array}$ & $\begin{array}{c}3 \\
(0.25)^{\mathrm{c}}\end{array}$ & $\begin{array}{c}1 \\
(0.25)^{b}\end{array}$ & $\begin{array}{c}15.8 \\
(0.1)^{\mathrm{b}}\end{array}$ & $\begin{array}{c}39 \\
(3.42)^{\mathrm{b}}\end{array}$ & $\begin{array}{c}31 \\
(3.83)^{\mathrm{b}}\end{array}$ & $\begin{array}{c}1.835 \\
(0.03)^{\mathrm{b}}\end{array}$ \\
\hline Moddikuruppan & $\begin{array}{c}127.2 \\
(10.0)^{\mathrm{b}}\end{array}$ & $\begin{array}{c}5 \\
(0.33)^{b}\end{array}$ & & & & & \\
\hline Murungakayan & $\begin{array}{l}110.7 \\
(4.9)^{\mathrm{c}}\end{array}$ & $\begin{array}{c}4 \\
(0.57)^{\mathrm{c}}\end{array}$ & 1.00 & $\begin{array}{c}17.3 \\
(0.1)^{\mathrm{a}}\end{array}$ & $53(2)^{\mathrm{a}}$ & $\begin{array}{c}26 \\
(4.5)^{\mathrm{b}}\end{array}$ & $\begin{array}{c}2.76 \\
(0.006)^{\mathrm{a}}\end{array}$ \\
\hline Suduheenati & $\begin{array}{c}112.5 \\
(7.96)^{\mathrm{c}}\end{array}$ & $\begin{array}{c}5 \\
(0.25)^{\mathrm{b}}\end{array}$ & 1.00 & $\begin{array}{c}14.6 \\
(0.6)^{\mathrm{b}}\end{array}$ & $32(1.5)^{b}$ & $\begin{array}{l}15.00 \\
(0.5)^{\mathrm{c}}\end{array}$ & $\begin{array}{c}1.496 \\
(0.06)^{\mathrm{b}}\end{array}$ \\
\hline Suwandal & $\begin{array}{l}115.6 \\
(8.8)^{\mathrm{c}}\end{array}$ & $\begin{array}{c}3 \\
(0.28)^{\mathrm{c}}\end{array}$ & & & & & \\
\hline Dahanala & $\begin{array}{c}95.6 \\
(2.7)^{\mathrm{d}}\end{array}$ & $\begin{array}{c}5 \\
(0.37)^{\mathrm{b}}\end{array}$ & 1.00 & $\begin{array}{c}15.5 \\
(0.7)^{\mathrm{b}}\end{array}$ & $\begin{array}{c}23 \\
(0.91)^{\mathrm{c}}\end{array}$ & $\begin{array}{c}12.00 \\
(0.23)^{\mathrm{c}}\end{array}$ & $\begin{array}{c}1.65 \\
(0.02)^{\mathrm{b}}\end{array}$ \\
\hline Halsudu wee & $\begin{array}{c}92.0 \\
(3.9)^{\mathrm{d}}\end{array}$ & $\begin{array}{c}7 \\
(0.50)^{\mathrm{a}}\end{array}$ & $\begin{array}{c}2 \\
(0.37)^{b}\end{array}$ & $\begin{array}{c}9.5 \\
(0.4)^{\mathrm{d}}\end{array}$ & $\begin{array}{c}18 \\
(1.43)^{\mathrm{c}}\end{array}$ & $\begin{array}{c}12 \\
(0.4)^{\mathrm{c}}\end{array}$ & $\begin{array}{c}1.622 \\
(0.09)^{\mathrm{b}}\end{array}$ \\
\hline Handiran & $\begin{array}{l}108.6 \\
(5.3)^{\mathrm{c}}\end{array}$ & $\begin{array}{c}3 \\
(0.33)^{\mathrm{c}}\end{array}$ & 1.00 & $\begin{array}{c}13.8 \\
(0.3)^{\mathrm{b}}\end{array}$ & $\begin{array}{c}33 \\
(1.33)^{\mathrm{b}}\end{array}$ & $\begin{array}{c}21 \\
(0.88)^{\mathrm{c}}\end{array}$ & $\begin{array}{c}2.087 \\
(0.059)^{\mathrm{a}}\end{array}$ \\
\hline Herathbanda & $\begin{array}{l}104.5 \\
(4.5)^{\mathrm{c}}\end{array}$ & $\begin{array}{c}3 \\
(0.28)^{\mathrm{c}}\end{array}$ & 1.00 & $\begin{array}{c}16.3 \\
(0.2)^{\mathrm{b}}\end{array}$ & $45(2.4)^{b}$ & $\begin{array}{c}18 \\
(1.20)^{\mathrm{c}}\end{array}$ & $\begin{array}{c}2.043 \\
(0.063)^{\mathrm{a}}\end{array}$ \\
\hline Kaluheenati & $\begin{array}{c}78.6 \\
(4.1)^{\mathrm{e}}\end{array}$ & $\begin{array}{c}3 \\
(0.51)^{\mathrm{c}}\end{array}$ & 1.00 & $\begin{array}{c}11.2 \\
(0.7)^{\mathrm{c}}\end{array}$ & $\begin{array}{c}28 \\
(5.97)^{\mathrm{c}}\end{array}$ & $\begin{array}{c}14 \\
(2.29)^{\mathrm{c}}\end{array}$ & $\begin{array}{c}1.36 \\
(0.13)^{\mathrm{b}}\end{array}$ \\
\hline Rathuheenati & $\begin{array}{c}110 \\
(6.4)^{\mathrm{c}}\end{array}$ & $\begin{array}{c}4 \\
(0.88)^{\mathrm{c}}\end{array}$ & $\begin{array}{c}3 \\
(0.5)^{\mathrm{a}}\end{array}$ & $\begin{array}{c}14.5 \\
(0.8)^{\mathrm{b}}\end{array}$ & $45(7.5)^{b}$ & $\begin{array}{c}18 \\
(4)^{\mathrm{c}}\end{array}$ & $\begin{array}{c}1.635 \\
(0.04)^{\mathrm{b}}\end{array}$ \\
\hline Kirimurunga & $\begin{array}{c}112.3 \\
(14.2)^{\mathrm{c}}\end{array}$ & $\begin{array}{c}5 \\
(0.88)^{\mathrm{b}}\end{array}$ & 1.00 & $\begin{array}{c}14.4 \\
(0.2)^{\mathrm{b}}\end{array}$ & $\begin{array}{c}20 \\
(0.88)^{\mathrm{c}}\end{array}$ & $\begin{array}{c}10.00 \\
(0.43)^{\mathrm{d}}\end{array}$ & $\begin{array}{c}2.19 \\
(0.008)^{\mathrm{a}}\end{array}$ \\
\hline Madael & $\begin{array}{c}89.9 \\
(7.0)^{\mathrm{d}}\end{array}$ & $\begin{array}{c}3 \\
(0.58)^{\mathrm{c}}\end{array}$ & $\begin{array}{c}1 \\
(0.4)^{\mathrm{b}}\end{array}$ & $\begin{array}{c}15.3 \\
(1.5)^{b}\end{array}$ & $\begin{array}{c}30 \\
(3.94)^{\mathrm{c}}\end{array}$ & $\begin{array}{c}17 \\
(1.96)^{\mathrm{c}}\end{array}$ & $\begin{array}{c}1.722 \\
(0.13)^{\mathrm{b}}\end{array}$ \\
\hline Masura & $\begin{array}{l}110.9 \\
(5.2)^{\mathrm{c}}\end{array}$ & $\begin{array}{c}3 \\
(0.37)^{\mathrm{c}}\end{array}$ & & & & & \\
\hline Pachchaperumal & $\begin{array}{c}98.2 \\
(0.6)^{\mathrm{d}}\end{array}$ & $\begin{array}{c}4 \\
(0.28)^{\mathrm{c}}\end{array}$ & $\begin{array}{c}2 \\
(0.33)^{\mathrm{b}}\end{array}$ & $\begin{array}{c}13.6 \\
(0.7)^{\mathrm{b}}\end{array}$ & $\begin{array}{c}29 \\
(7.81)^{\mathrm{c}}\end{array}$ & $\begin{array}{c}14 \\
(3)^{\mathrm{c}}\end{array}$ & $\begin{array}{c}1.403 \\
(0.02)^{\mathrm{b}}\end{array}$ \\
\hline Pokkali & $\begin{array}{c}115.1 \\
(12.5)^{\mathrm{c}}\end{array}$ & $\begin{array}{c}5 \\
(0.66)^{b}\end{array}$ & $\begin{array}{c}2 \\
(0.33)^{b}\end{array}$ & $\begin{array}{c}13.1 \\
(0.8)^{\mathrm{b}}\end{array}$ & $\begin{array}{c}30 \\
(0.66)^{\mathrm{c}}\end{array}$ & $\begin{array}{c}18 \\
(2.51)^{\mathrm{c}}\end{array}$ & $\begin{array}{c}1.951 \\
(0.09)^{\mathrm{b}}\end{array}$ \\
\hline Pokkaliyan & $\begin{array}{c}115.3 \\
(14.3)^{\mathrm{c}}\end{array}$ & $\begin{array}{c}3 \\
(0.33)^{\mathrm{c}}\end{array}$ & $\begin{array}{c}2 \\
(0.5)^{\mathrm{b}} \\
\end{array}$ & $\begin{array}{c}18.9 \\
(0.2)^{\mathrm{a}}\end{array}$ & $\begin{array}{c}70 \\
(6.5)^{\mathrm{a}} \\
\end{array}$ & $\begin{array}{c}45 \\
(5)^{\mathrm{a}}\end{array}$ & $\begin{array}{c}1.92 \\
(0.03)^{\mathrm{b}}\end{array}$ \\
\hline Suduru samba & $\begin{array}{c}95.3 \\
(2.1)^{\mathrm{d}}\end{array}$ & $\begin{array}{c}4 \\
(0.40)^{\mathrm{c}}\end{array}$ & & & & & \\
\hline Godaheenati & $\begin{array}{l}130.8 \\
(4.0)^{\mathrm{a}}\end{array}$ & $5(1)^{b}$ & $\begin{array}{c}2.00 \\
(0.6)^{\mathrm{b}}\end{array}$ & $\begin{array}{c}17.3 \\
(0.6)^{\mathrm{a}}\end{array}$ & $\begin{array}{c}68 \\
(18.9)^{\mathrm{a}}\end{array}$ & $\begin{array}{c}30 \\
(3.17)^{b}\end{array}$ & $\begin{array}{c}2.327 \\
(0.127)^{\mathrm{a}}\end{array}$ \\
\hline Madathawalu & $\begin{array}{c}92.9 \\
(4.2)^{\mathrm{d}}\end{array}$ & $\begin{array}{c}3 \\
(0.33)^{\mathrm{c}}\end{array}$ & 1.00 & $\begin{array}{c}11.5 \\
(0.5)^{\mathrm{c}}\end{array}$ & $44(4)^{b}$ & $\begin{array}{c}16 \\
(2.5)^{\mathrm{c}}\end{array}$ & $\begin{array}{c}1.705 \\
(0129)^{\mathrm{b}}\end{array}$ \\
\hline Behethheenati & $\begin{array}{c}98.7 \\
(4.4)^{\mathrm{d}}\end{array}$ & $\begin{array}{c}7 \\
(0.86)^{\mathrm{a}}\end{array}$ & 1.00 & $\begin{array}{c}12.9 \\
(.09)^{\mathrm{c}}\end{array}$ & $\begin{array}{c}61 \\
(21.5)^{\mathrm{a}}\end{array}$ & $\begin{array}{c}43 \\
(17)^{\mathrm{a}}\end{array}$ & $\begin{array}{c}0.977 \\
(0.022)^{\mathrm{c}}\end{array}$ \\
\hline Rathsuwandal & $\begin{array}{c}97 \\
(9.5)^{\mathrm{d}}\end{array}$ & $\begin{array}{c}4 \\
(0.28)^{\mathrm{c}}\end{array}$ & $\begin{array}{c}2 \\
(0.25)^{\mathrm{b}}\end{array}$ & $\begin{array}{c}15.4 \\
(1.5)^{\mathrm{b}}\end{array}$ & $\begin{array}{c}66 \\
(20.6)^{\mathrm{a}}\end{array}$ & $\begin{array}{c}38 \\
(7.30)^{\mathrm{a}}\end{array}$ & $\begin{array}{c}0.910 \\
(0.014)^{\mathrm{c}}\end{array}$ \\
\hline
\end{tabular}

The mean values are followed standard deviation within parenthesis. The same letter along the columns indicates no statistically significant difference at $\mathrm{p} \leq 0.05$.

Means of shoot length and leaf width were shown graphically in Fig.1 and 2.Varieties such as Murungakayan, Suwandal, Rathuheenati, Kirimurunga, Suduru samba and RathSuwandal were able to regain shoot length compared to the control after drought period (Fig.1). Certain varieties such as Murungakayan, SuwandalandKirimurungashowed tolerance by surviving in the induced drought duration. Thus, the results indicate that Murungakayan, Suwandal and Kirimurunga possess ability for drought tolerance and recovery after a drought period. 


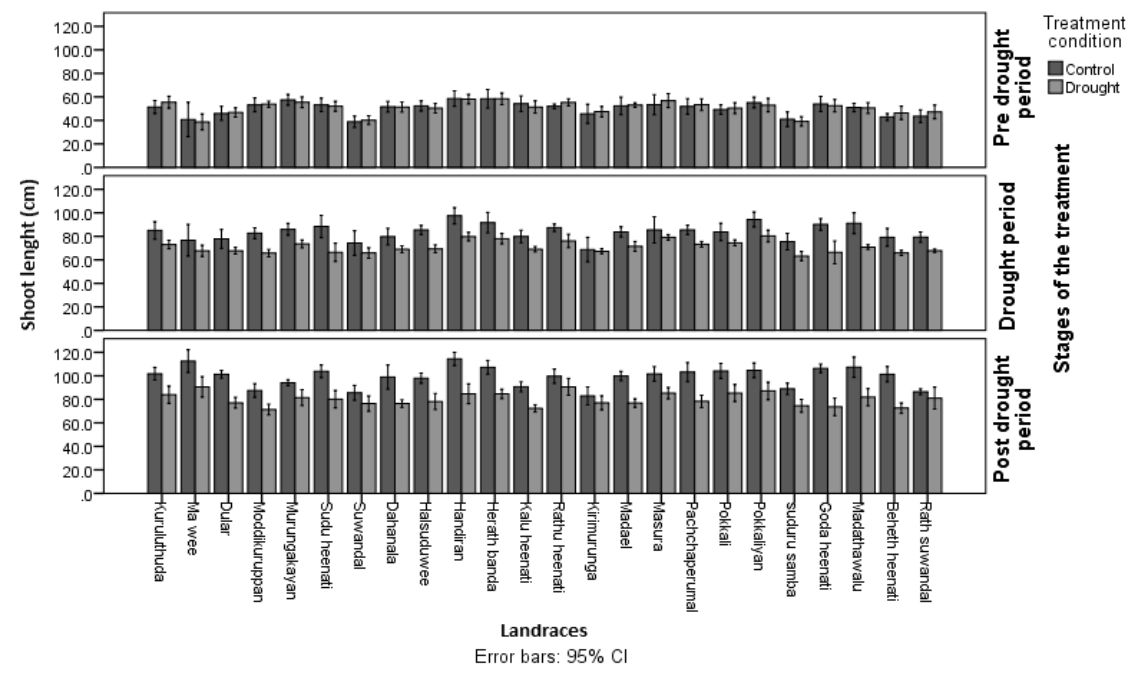

Fig. 1. The influence of drought on the shoot length of rice landraces under different water regimes.

Similar approach can be used to describe the patterns in Fig.2. The cultivars such as Ma wee, Suwandal, Kalu heenati, Kirimurunga, Pachchaperumal, Suduru samba and Beheth heenatiregained to leaf width after the drought period compared to the control. Cultivars Mawee and Kirimurunga were able to regain the leaf width as in the control indicating tolerance to drought. This implies that Mawee and Kirimurunga have both tolerance and ability to in drought. However, the drought reference cultivar Dular showed different results in this study. Comparatively, certain local cultivars have showed better resistance and recovery potential than Dular.

Leaf width is reduced due to leaf rolling which reduce the transpiration during a drought stress. According to Rauf et al. (2016), this dehydration avoidance mechanism was brought by two possible ways by altering the leaf tissue structure. They are by bulliform cells which are adaxial cells in the epidermis of the leaf and large hypodermal cells shrinking due to loss of water or to a differential distribution of schlerenchyma cells. Stunting is apparently a temperature response to drought rather than avoidance mechanism. Drought causes reduction of cell by losing cell water content and ultimately the growth of the plant (Hasanuzzamanet al., 2013). In the present study, regaining of shoot height and leaf width was observed. This indicates that plant is readjusting to initial metabolic state after a drought period. However, it is not clear the mechanism how plants regain the initial stage after drought stress (Lyon et al., 2016). 


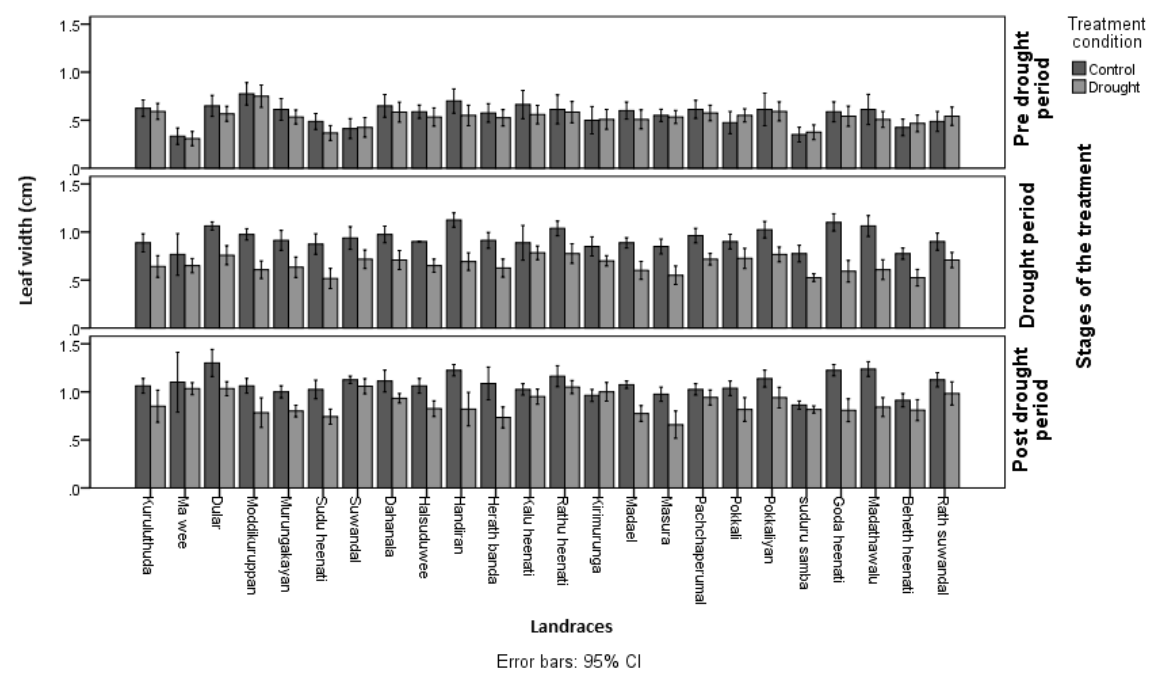

Fig. 2. The influence of drought on the leaf width of rice landraces under different water regimes.

Even though certain cultivars were not represented in Fig. 1 and 2, which gave an indication of how cultivars responded to drought and how they recovered after a drought period. Despite the fact that, the cultivars Murungakayan, Rathuheenati and Rathsuwandal were able to regain the shoot length, they showed poor recovery in leaf width. In contrary, the cultivars Mawee, Kaluheenati, Pachchaperumal and Behethheenati were poor in recovering shoot length. A cultivar which possesses both tolerance and recovery can be considered as an resistant variety to drought (Zulkarnainet al., 2009). Thus, according to the results of this study, Suwandal, Kirimurunga and Suduru samba could be identified as better varieties compared to Dular.

With reference to RM product size (216bp), only the RM252 indicated bands in the agarose gel and the rest of the markers used in the study did not produce bands. In this study, it was observed that RM252 could be considered as a potential marker for tracing the drought tolerance in rice landraces. However, the results of agro-morphological characterization and molecular analysis have indicated divisive findings. Even though, the land races Halsudu wee, Handiran, Herath Banda, Madeal, Pokkali and Pokkaliyan produced bands in the gel, they did not show morphological characteristics of drought tolerance (Fig. 3). In contrary, the land races Suwandal, Kirimurunga and Suduru samba indicated a potential drought resistance while lacking any band patterns in the gel. The land races Rathuheenatiand Behethheenati demonstrated drought tolerance implying these land races possibly possess drought resistance at the gene level. In addition to molecular and morphological evidences, anatomical and physiological evidences should seek for the establishment of drought tolerance of rice landraces. 


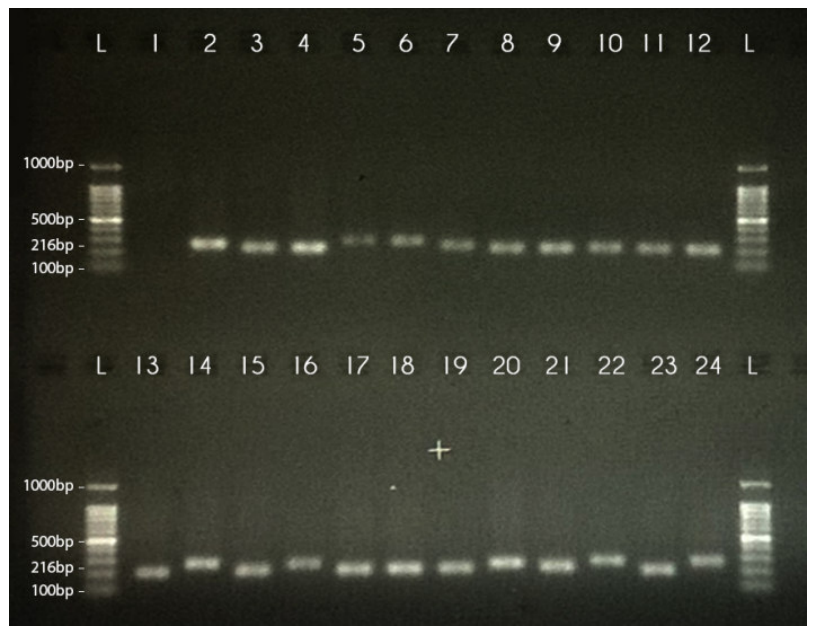

Fig. 3. DNA profile of the 24 rice land races with SSR marker RM 252 . Legend: $1=$ Kuruluthuda; 2= Mawee; 3= Dular; 4= Moddikuruppan; 5= Murungakayan; 6= Suduheenati; $7=$ Suwandal; 8= Dahanala; 9= Halsuduwee; 10 $=$ Handiran; 11 $=$ Herathbanda; 12= Kaluheenati; 13= Rathuheenati; 14 $=$ Kirimurunga; 15= Madeal; 16= Masura; 17= Pachchaperumal; 18= Pokkali; 19=Pokkaliyan; 20= Suduru samba; 21=Godaheenati; 22= Madathawalu; 23= Behethheenati; 24= Rathsuwandal; $\mathbf{L}=$ Ladder DNA

\section{CONCLUSION}

The results of this study revealed that drought tolerance is directly associated with phenotypic variation and indirectly related to gene level manifestation. The landraces Suwandal, Kirimurunga and Suduru samba were found to be drought tolerant. The SSR marker RM252 is a potential candidate as marker for tracing drought tolerance in rice landraces.

\section{REFERENCES}

Boonjung, B. and Fukai,S.(1996). Effects of soil water deficit at different growth stages on rice growth and yield under upland conditions. 1. Growth during drought. Field Crops Res. $48,37-45$.

Chaves, M.M., Flexas, J. and Pinheiro, C. (2009). Photosynthesis under drought and salt stress: regulation mechanisms from whole plant to cell. Ann. Bot. 103, 551 - 560.

De Costa, W.A.J.M., Wijeratne, M.A.D. and De Costa, D.M. (2012). Identification of Sri Lankan rice varieties having osmotic and ionic stress tolerance during the first phase of salinity stress. J.Nati. Sci. Found. Sri Lanka. 40, 251-280.

Department of Census and Statistics, Paddy Statistics (2015) [on line]. [Accessed on 30.06.2016]. Available at 
http://www.statistics.gov.lk/agriculture/Paddy\%20Statistics/PaddyStats.html

Farooq, M., Wahid, A., Kobayashi, N., Fujita, D. and Basra, S.M.A. (2009). Plant drought stress: mechanisms and management. Agron.for Sustainable Development. 29, 185-212.

Hasanuzzaman, M., Nahar, K., Alam, M., Roychowdhury, R. and Fujita, M. (2013). Physiological, Biochemical and molecular Mechanism of heat Stress Tolerance in Plant. Int. J. Molecular Sci. 14, 9643-9684.

Hoque, M. andKobata, T. (1998) Growth Responses of Drought Resistant Rice Cultivars to Soil Compaction under Irrigated and Succeeding Non-irrigated Conditions during the Vegetative Stage. Plant Prod. Sci. 1, 183-190.

Islam, A.S.M.F., Ali, M.R., Gregorio, G.B.andIslam, M. R. (2012) Genetic diversity analysis of stress tolerant rice (Oryzasativa L.). African J. Biotech. 11, 15123 - 15129.

Khowaja, F.S., Norton, G.J., Courtois, B.andPrice, A.H. (2009). Improved resolution in the position of drought-related QTLs in a single mapping population of rice by meta-analysis http://www.ncbi.nlm.nih.gov/pmc/articles/PMC2708188/

Kumar, B., Gomez, S.M., Boopathi, N.M., Kumar, S.S., Kumaresan, D., Biji, B.J., Babu, B.K., Prasad, N.S.R., Shanmugasundaram, P. and Babu R.C. (2005). Identification of Microsatellite Markers Associated with Drought Tolerance in Rice (Oryzasativa L.) using Bulked Line Analysis. Trop. Agric. Res. 17, 39 - 47.

Lyon, D., Castillejo, M.A., Mehmeti-Tershani, V., Staudinger, C., Kleemaier, C.andWienkoop, S. (2016). Drought and Recovery: Independently Regulated Processes Highlighting the importance of Protein Turnover Dynamic and Translational Regulation in Medicagotruncatula. Molecular \& Cellular Proteomics. 15, 1921-1930.

Matin, S., Ashrafuzzaman, M., Monirul Islam, M.D., Sikdar, S.U.andZobayer, N., (2012). Molecular marker based (SSR) genetic diversity analysis in deep water rice germplasms of Bangladesh, Int. J.Biosci. 2, 264 - 72.

Mostajeran, A. and Rahimi-Eichi, V. (2009). Effects of Drought Stress on Growth and Yield of Rice (Oryza sativa L.) Cultivars and Accumulation of Proline and Soluble Sugars in Sheath and Blades of Their Different Ages Leaves. American-Eurasian J. Agric. \& Environ. Sci. 5, $264-272$.

Ranawaka, A.L. and Dahanayake, N. (2012). Understanding abiotic stress tolerant levels and mechanisams in some traditional rice cultivars in Sri Lanka. $9^{\text {th }}$ Academic session, University of Ruhuna, p 23.

Ranawake, A.L. and Amarasinghe, U.G.S. (2014). Trait effect in different days to flowering groups of rice. Int. J. Sci. and Res. Publications. 4, 7.

Rauf, S., Al-khayri, J.M., Zaharieva, M., Monneveux, P. and Khalil, F. (2016). Breeding stratagies to Enhance Drought Tolerance in crops. pp. 365-370 In: Khayri, J.M. et al., (Eds.) Adv. Plant Breeding Strategies. Springer International Publications., Switzerland. 
Sharma, P. and Dubey, R.S. (2005). Drought induces oxidative stress and enhances the activities of antioxidant enzymes in growing rice seedlings. Plant Growth Regulation. 46, $209-221$.

Sharma, G. and Rai, L.K. (2010). Climate Change and Sustainability of Agrodiversity in Traditional Farming of the Sikvkim Himalaya, Mountain Institute of India. United Nations University, Tokyo and MacArthur Foundation.

Somaratne, S. and Dhanapala, A.H. (1996). Potential impact of global climate change on forest distribution in Sri Lanka. pp 129-135. In:Water Air Soil Pollutes.Springer International Publications., Switzerland.

Wassmann, R., Jagadish, S.V.K., Sumfleth, K., Pathak, H., Howell, G., Ismail, A., Serraj, R., Redona, E., Singh, R.K.andHeuer, S., (2009). Regional Vulnerability of Climate Change Impacts on Asian Rice Production and Scope for Adaptation. Adv. Agro.102, 58-92.

Zulkarnain, W.M., Ismail, M.R., Ashrafuzzaman, M., Saud, H.M. andHaroun, I.C. (2009). Growth, Physiological and Biochemical Responses of Malaysia Rice Cultivars to Water Stress. Pertanika J.Tropi. Agric. 32,323-333. 